\title{
Gen Z's altruism and performance values link to private label preference: first evidence from a German drugstore sample
}

\author{
Joern Redler \\ School of Business, Mainz University of Applied Sciences, Mainz, Germany \\ Joachim Hurth \\ Department of Business Administration \\ Ostfalia University of Applied Sciences, Wolfsburg, Germany
}

\section{Keywords}

Generation Z, store brands, private label, retail management, values

\begin{abstract}
The purpose of this research is to examine the link between Gen Z's values and private label acceptance. It aims at better understanding future generations' openness to retailer's private label brands, a factor highly relevant for channel strategies. Based on survey data, a sample of 3,194 consumers was explored. Descriptive and inferential statistical methods were used (a) to examine consumer perceptions of private labels, (b) to understand private label usage, and (c) to link Gen Z's values to customer evaluations and reported buying. The findings indicate that Gen $Z$ consumers are characterized by the value factors (I) altruism, (II) performance orientation, (III) hedonism, and (IV) sense of family. Further, the factors (I) and (II) were identified to be particularly relevant for private label brand positioning. The paper is unique as it is the first empirical investigation of Gen Z's private label brand preference in the context of retailing and distribution channel strategy.
\end{abstract}

\section{Introduction and purpose}

Private label brands (PLB), also known as own brands or store brands, are brands owned, controlled, and mostly exclusively sold by a retail chain (Kremer and Viot, 2012; Kumar, 2007; Baltas, 1997; Pauwels and Srinivasan, 2004). PLB usually comprise a strong linkage with the retailer, especially if the retailer name is used for branded products. The corresponding counterpart to PLB is national brands (NB), managed by producing firms.

Private labels have been extremely successful in the past as well as in recent years (Sebri and Zaccour, 2017; Geyskens, Keller, Dekimpe and de Jong, 2018). The dollar volume from mass retailer's private label brands climbed 41\% from 2013 to 2018 while national brands only increased by 7\%, according to a report from the Private Label Manufacturers Association (PLMA) that analyzed Nielsen data. Moreover, this impressive growth for private label shows no sign of slowing (PLMA, 2019). Steenkamp and Geyskens (2014) point out that the growth of PLB has outpaced national brand growth every year in the $21^{\text {st }}$ century. "There is a new retail revolution underway and it's going to affect the food industry across the globe over the next five years in ways we have never seen before... Nielsen information across 60 countries shows that private-label products continue to gain share across all major geographies" (Nielsen US, 2018, p. 2).

While Seenivasan, Sudhir and Talukdar (2016) state that the United States has caught up during the last recession, and retailers continue to invest in growing store brands, Western Europe is by far the most developed PLB region in the world (Ter Braak, Geyskens and Dekimpe, 2014). Germany has a very high level of PLB turnover in the fast-moving goods industry with about $40 \%$ of turnover. In some categories, the market share of PLB is much higher than $50 \%$ e.g. in foils/baking paper, in paper hygiene, and household items.

Beyond the growing market share, an increase of PLB's quality can be observed. Initially created to provide the cheapest product in the assortment, PLB have evolved from generics to products with quality that is comparable to national brands (Keller, 2017). In some categories, they are among the strongest brands in the market. American examples are Great Value (generic) or Sam`s Choice (premium) by Wal Mart. Nowadays, PLB are a constituent part of retailers' assortments. They seem to be a success factor for retailers in the Western world (Labeaga, Lado and Martos, 2007) and a relevant competitor to national 
brands. Consequently, over the last decades, PLB have emerged as a well-considered topic for management and academic research. Researchers have provided numerous conceptual and empirical insights. Competitive (Pauwels and Srinivasan, 2004), consumer-related (Baltas and Argouslidis, 2007), and retailer-related (Ailawadi and Harlam, 2004) key factors influencing PLB success have been examined. However, these conclusions refer to current consumer cohorts and do not take into account the upcoming generational change. To anticipate private label brands' future roles for customers, research and management are required to carefully monitor changes involved in coming consumer cohorts. One widely discussed manifestation of the impending change in this regard is the move from generation $X$ (Gen X) to generation Y (Gen Y) to generation Z (Gen Z, e.g. Kitchen and Proctor, 2015). Whereas Gen X consumers were born during 1965-1980, Gen Z consumers refer to persons born from 1995 on. Gen Y (also called Millennials) and Gen $Z$ are often combined and share many characteristics. What especially sets Gen $\mathrm{Z}$ apart is that they are the first generation of digital natives. Recognizing that Gen $\mathrm{Z}$ is the next generation of buyers that retailers need to focus on, one consequence will be that retailers are going to face new value systems and behaviors of their (potential) buyers. Remarkably, the question of how this will affect the acceptance and use of PLB, as one of the most important strategic issues for the current retail business, has not been addressed yet. In particular, Gen Z's attitude towards PLB, their PLB product acceptance, and PLB purchase behavior have remained a neglected field in the study of PLB. Against this background, this paper reports a study that investigates how Gen Z's values relate to private label evaluation and usage. The study is based on a comprehensive consumer sample from the German retail context. The study will help to better understand the forthcoming challenges for retail and brand management.

\section{Literature review and theoretical background}

\section{Private Label Brands}

Concerning attitudes and purchase intention towards PLB, Gomez-Suárez, Quinones and Yagüe (2017) have recently done a comprehensive compilation of academic papers. Table 1 takes up important studies covered there and also adds findings from a further literature review. Another exhaustive review of related literature is provided by Hyman, Kopf and Lee (2010) which includes 60 empirical studies. Further, a literature overview on PLB and food retailing was presented by Olbrich, Hundt and Jansen (2016), lately.

It was Myers (1967) study that pioneered academic research on PLB. From that on, research on that topic has increased significantly, especially in the last twenty years. The consumer perspective dominates manufacturer's and retailers' perspectives (Gomez-Suárez, Quinones and Yagüe, 2017). There are several explanations why PLB have increased in importance. First, they allow for higher margins from the retailer's perspective (e.g. Ailawadi and Harlam, 2004). Second, they support retailers in their struggle for increasing power in the supply chain system (Olbrich and Grewe, 2013). Third, consumers give less importance to national brands today and have developed a positive attitude towards PLB products as its perceived quality improved (e.g. DelVecchio, 2001), leading to increased perceived value that drives purchase decisions in favor of PLB (e.g. Walsh and Mitchell, 2010). In essence, quality beliefs towards PLB do vary less from those of NB, and consumers' confidence in PLB products is even backed up by the perception of PLB being cheaper (Richardson, Jain and Dick, 1996; Sinha and Batra, 1999). Fourth, PLB assortment is a means to supporting uniqueness of the retailer's brand (e.g. Collins-Dodd and Lindley, 2003). Fifth, offering PLB may also lead to increased store loyalty (e.g. Corstjens and Lal, 2000; Ailawadi, Pauwels and Steenkamp, 2008; Gonzalez-Benito and Martos-Partal, 2012). 
PLB product success has been modelled by Hoch and Banerij (1993). They consider consumerrelated (as product quality and quality consistency), retailer-related (as category retail sales and category margins), and national manufacturer-related determinants (like the number of national manufacturers and national advertising per manufacturer). Further studies on factors explaining the success of PLB stem from Erdem, Zhao and Valenzuela (2004) or Rubio and Yagiie (2009). As a reaction to PLB' success, retailers have professionalized in terms of product brand management; more and more they operate alike their national brand when it comes to product brand management (Davis, 2013; PLMA, 2013).

\begin{tabular}{|c|c|c|}
\hline Author(s), year & PLB relevant outcome variable & Antecedent variable \\
\hline $\begin{array}{l}\text { Richardson et al., } \\
1996\end{array}$ & Perceived quality & Store aesthetics \\
\hline Baltas, 1997 & Attitude & $\begin{array}{l}\text { Smart shopping } \\
\text { Variety seeking }\end{array}$ \\
\hline Batra \& Sinha, 2000 & Attitude & $\begin{array}{l}\text { Price consciousness } \\
\text { Perceived risk }\end{array}$ \\
\hline DelVecchio, 2001 & Perceived quality & Product category \\
\hline $\begin{array}{l}\text { Martínez \& } \\
\text { Montander, } 2008\end{array}$ & Attitude & $\begin{array}{l}\text { Price consciousness } \\
\text { Innovation }\end{array}$ \\
\hline Ailawadi et al., 2008 & Private label usage & Behavioral loyalty \\
\hline Hsu \& Lai, 2008 & Purchase intention & $\begin{array}{l}\text { Category "search" } \\
\text { characteristics }\end{array}$ \\
\hline Glynn \& Chen, 2009 & Attitude towards PLB buying & $\begin{array}{l}\text { Price consciousness } \\
\text { Brand loyalty } \\
\text { Category "search" } \\
\text { characteristics } \\
\text { Perceived risk }\end{array}$ \\
\hline Diallo et al., 2013 & Purchase intention & Value consciousness \\
\hline Beneke et al., 2013 & Purchase intention & $\begin{array}{l}\text { Perceived quality } \\
\text { Perceived risk }\end{array}$ \\
\hline Miquel et al., 2017 & Purchase intention & Gender \\
\hline
\end{tabular}

Table 1: Summary of important studies on PLB, grouped by antecedents and dependent variables

\section{Private label and buying behavior}

Richardson, Jain and Dick (1996) present a comprehensive framework to understand consumer's buying responses to PLB. Following their argument, consumers' propensity to buy PLB depends on demographic factors, personal factors, and consumers' perceptions. Personal variables focus on the consumers' tolerance of risk and the degree of reliance on extrinsic cues (which are typically stronger for national brands). Perceptions refer to aspects like the level of perceived risk, the degree of perceived quality variation and the perceived value for money. These are triggered by category knowledge.

Demographic factors: All in all, empirical research has not been able to give support to typical socio-demographic profiles of consumers preferring PLB (Burt and Davies, 2010, also see the summary of these variables in Olbrich, Hundt and Jansen, 2016). But although socio-demographic variables remain critical for explaining choice between PLB and NB (Rondan Cataluña, García and Phau, 2006), Ailawadi, Neslin and Gedenk (2001) emphasize the indirect effect: Socio-demographics have a strong influence on psychographics that, in turn, relate to effective buying behavior. For example, age as a demographic variable will determine the prevalent values and attitudes of a cohort, and that might impact on PLB preference. This might mean that future younger cohorts may have different values and also show different attitudes toward PLB.

Personal factors: Personal factors influencing PLB purchase have been examined mainly in terms of price-consciousness (price-orientation) and customer value-consciousness. According to Lichtenstein, Ridgway and Netemeyer (1993), price-consciousness is defined as the extent to which the consumer focuses on paying low prices. This construct has been discussed early as an influence on PLB purchase 
(e.g. Burger and Schott, 1972; Rothe and Lamont, 1973). Newer studies support that price-consciousness positively influences consumers' PLB product purchasing decisions (Baltas, 1997; Batra and Sinha, 2000; Hsu and Lai, 2008). A construct that only partly overlaps with price-consciousness is customer valueconsciousness. Dick, Jain and Richardson (1995) define it as the consumers' evaluation of the product quality relative to the product's price. Research has shown that value-related measures positively relate to PLB attitude and usage (Burton, Lichtenstein, Netemeyer and Garretson, 1998; Richardson, Jain and Dick, 1996). Burton, Lichtenstein, Netemeyer and Garretson (1998, p. 294), however, focus on attitude toward PLB as the main influence on PLB usage. They also highlight its role as a mediator between other influences and PLB purchase. As they explain, "for example, consumers may view private label products positively due to a desire to pay low prices (i.e., price consciousness), or a strong desire to maximize the ratio of quality received to the price paid (i.e., value consciousness), or view them negatively because they believe that price is a strong indicator of quality (i.e., a price-quality schema)."

PLB perceptions: For consumers, PLB are attractive as they offer comparatively high-quality products at competitive price levels (Davis, 2013; Pauwels and Srinivasan, 2004). The perceived pricequality relation of PLB has been the focus of several examinations (e.g. Sethuraman and Cole, 1997; Beneke, Flynn, Greig and Mukaiwa, 2013). Generally speaking, it may be stated that relationships between the perceived price-quality relation and PLB product preference exist and that a decent perceived pricequality relation might be seen as a major motive for PLB purchase. Product quality per se had been incorporated in the model by Hoch and Banerij (1993). There, quality consistency was another consumerrelated variable to be considered. Several approaches analyze these viewpoints as a question of perceived risk (e.g. Batra and Sinha, 2000; Beneke, Flynn, Greig and Mukaiwa, 2013). As the retail industry has seen an enormous growth of PLB product share, product-related and marketing-related differences between national brands and PLB seem to become more and more negligible. Closing the quality gap with national brands is one of the success factors for private labels (Steenkamp and Geyskens, 2014). In this context, Boyle and Lathrop (2013) found out that based on an analysis of "objective" product evaluation in the American consumer report, the average quality of private labels is very close to the average quality of NB. Several recent studies found evidence for the quality gap to be closed in the perception of the consumers. According to Nielsen, PLB represent a good alternative to NB for $75 \%$ of US consumers, $70 \%$ of Europeans, and $58 \%$ of Asian shoppers (Nielsen Global Services, 2005). 74\% of American customers state that a private label is now better value for the money, $61 \%$ say quality has improved, $84 \%$ say that private label quality is at least as good, and $61 \%$ of the sample purchase more private brand products than two years before (Daymon, 2018). In Germany, $85 \%$ of the respondents of a representative study believe that the quality of PLB is as good as the quality of national brands (Ipsos and Lebensmittelzeitung, 2017). All in all, private labels by now are a "widely accepted brand class of their own" (Seenivasan, Sudhir and Talukdar, 2016, p. 802).

PLB, culture, and values: One factor that has been analyzed only rarely is the link between basic values and PLB acceptance. Erdem, Zhao and Valenzuela (2004) identified uncertainty in terms of quality, learning and perceived risk as relevant factors for consumer's PLB choice. Several times, value disposition has been discussed as factors explaining PLB shopping differences between countries. E.g. Lupton, Rawlinson and Braunstein (2010) discussed differences between the Western individualistic and Eastern collectivistic cultures. For the Mediterranean countries, Herstein, Tifferet, Abrantes, Lymperopoulos, Albayrak and Caber (2012) found that the predisposition to buy PLB is significantly influenced by personality traits. Based on advertising expenditure in 37 countries, Deleersnyder, Dekimpe, Steenkamp and Leeflang (2009) concluded that PLB growth is lower in countries with higher uncertainty avoidance. 


\begin{tabular}{|c|c|c|c|}
\hline & Gen $X$ & Gen $Y$ & Gen Z \\
\hline $\begin{array}{l}\text { Years of birth } \\
\text { (Williams et al., 2010) }\end{array}$ & $1965-1977$ & $\begin{array}{l}1978-1994 \\
\text { (Millennials) }\end{array}$ & 1995 - \\
\hline
\end{tabular}

Aspects of lifestyle Independence and Self-absorbed; self- Self-actualization; and attitudes individualism; reliant; emotionally traditional beliefs; (Williams et al., 2010) search for meaning; and intellectually family; confident balance, family; life expressive; image- and optimistic, and work; skeptical driven; network- authenticity, need of authority; anti- driven; optimism to belong / peermaterialistic, acceptance impatient

$\begin{array}{lll}\text { Communication } & \text { Centralized, E- Collaborative, } & \text { Collaborative, } \\ \text { (Roth and Nazemian, Mail, mobile phone Web 2.0 } & \text { social media, high- } \\ 2019) & \text { tech }\end{array}$
Table 2: Overview of Gen X, Gen Y and Gen Z

\section{Gen Z}

Gen Z refers to young adults born after 1994 (Williams, Page, Petrosky and Hernandez, 2010; Dimock, 2019; it might be noted that in literature other definitions exist, too). The Gen $Z$ cohort is well educated, innovative and technologically savvy (Merriman, 2015). Gen Z differs from other generations in terms of behavior, with implications for consumer behavior (Schlossberg, 2016). A reason for that might be seen in a modified value cluster, which separates them from former generations. As research has exhibited (e.g. Williams, Page, Petrosky and Hernandez, 2010; Ordun, 2015), the different generations are characterized by contrasting lifestyles and embody different value clusters that, inter alia, trigger buying behavior. Table 2 gives a brief overview of the main differences between the three generations. All in all, Gen Z individuals are considered "new conservatives", characterized by rather traditional beliefs (Williams, Page, Petrosky and Hernandez, 2010). On the other hand, Gen Z is globally oriented and is more than ever a mixture of persons with diverse backgrounds, encompassing different ideas and experiences, showing a high acceptance for cultural, sexual or racial diversity (Shatto and Erwin, 2016). Compared to past generations, they have access to more information ever. Peer acceptance seems important to them, and the self-concept is strongly built on the individual's reference group (Soltan, 2004). Gen $Z$ is also highly tolerant and prefers written communication to oral communication (Chaney, Touzani and Slimane, 2017). Shatto and Erwin (2016) maintain that Gen Z individuals have shortcomings in terms of critical thinking so that the ability to evaluate the validity of information is poor; furthermore, their social and emotional skills are rather poor.

Gen Z and shopping: Though some initial systematic research on general characteristics of Gen Z has been published, only little research has turned towards discussing the implications of Gen $Z$ and shopping behavior or consumption. However, some shopping-related characteristics of Gen Z individuals have been identified by the Criteo Shopper Study (Criteo, 2017): One is that before buying a product, Gen $\mathrm{Z}$ consumers will consult their network (online and/or offline). Secondly, online shopping is the most common way of buying products for Gen $\mathrm{Z}$, but they also long for real, tactile shopping experiences and possibilities to explore products in offline shops, and finally, they excessively use retailers' websites as a source of information. According to Schlossberg (2016), Gen Z consumers have only little brand loyalty, have high expectations and put emphasis on experience. Turning to retail and channel management it seems noteworthy that Gen Z consumers are considered to be less loyal to retailers and channels, putting pressure on each and every retailer to find new ways to attract and retain consumers' attention (Merriman, 2015).

\section{Study}

Regarding the findings on Gen Z's different lifestyle and value system, the question arises how this will impact on PLB acceptance and PLB purchase. How does the upcoming generation's value system 
relate to PLB? Most remarkably, neither conceptual papers nor empirical work have addressed this issue yet. To inaugurate consideration of this relevant link, a study was conducted which explores Gen Z's value patterns and examines their association to PLB attitude.

Data, sample, and sampling procedure

Data was collected using an online survey. The participants were sampled from followers of a social media channel of a German drugstore retail chain. 3,194 consumers participated in this study, most of them being younger than 30 years. Only a few were older than 38 years. The average age was between 21 and 22 years. $99 \%$ of the sample was female. All in all, two groups were covered: Gen Z $(2,522$ consumers up to 23 years) and Gen Y (651 consumers between 24 and 38 years). Field time was September 2018. The following analyses refer to the Gen $\mathrm{Z}$ participants. For participant acquisition, young facebook-followers of the retail chain were asked to participate in the survey and to complete a questionnaire. They were offered to participate in a lottery, for motivation reasons. Filling in the questionnaire took about 5 minutes per participant.

\section{Measures}

Apart from personal descriptors and questions on buying behavior and PLB usage, the questionnaire included measures for Gen Z-relevant values and attitudes towards PLB. Gen Z-relevant values were assessed using 14 items taken from an established longitudinal research project by the German ministry for the environment (BMU, 2018). Following the BMU approach, the scaling type was a 4-point Likert version ranging from $1=$, it is very important to me“ to $4=$, it is not important at all to me“ (translated from German). Examples for covered items are (translated from German): "to have good friends", "to have a trustworthy partner", "to enjoy life" or "to make new experiences again and again".

\begin{tabular}{|c|c|c|c|c|}
\hline & \multicolumn{4}{|c|}{ Component/Factor } \\
\hline & 1 Altruism & $\begin{array}{c}2 \\
\text { Performance }\end{array}$ & 3 Hedonism & $\begin{array}{l}4 \text { Sense of } \\
\text { family }\end{array}$ \\
\hline $\begin{array}{l}\text { To help socially disadvantaged } \\
\text { people and marginalized groups }\end{array}$ & .770 & .042 & .061 & .062 \\
\hline To engage in political life & .689 & .139 & -.043 & -.081 \\
\hline $\begin{array}{l}\text { To act environmentally conscious } \\
\text { under any circumstances }\end{array}$ & .683 & .111 & .077 & .092 \\
\hline $\begin{array}{l}\text { To assume responsibility for the } \\
\text { common good }\end{array}$ & .646 & .161 & .179 & .160 \\
\hline $\begin{array}{l}\text { To respect and recognize the } \\
\text { diversity of mankind }\end{array}$ & .640 & -.021 & .178 & .004 \\
\hline To have a good education & .106 & .748 & -.085 & .096 \\
\hline $\begin{array}{l}\text { To integrate fulfillment and } \\
\text { success into professional life }\end{array}$ & .194 & .662 & .180 & .111 \\
\hline To be able to buy what I like & -.055 & .539 & .396 & -.141 \\
\hline To enjoy the life of the full & .084 & .031 & .816 & .094 \\
\hline $\begin{array}{l}\text { To make new experiences again } \\
\text { and again }\end{array}$ & .327 & .109 & .643 & .063 \\
\hline To have a trustworthy partner & -.065 & .021 & .021 & .745 \\
\hline To have a good family life & .099 & .039 & .092 & .737 \\
\hline To live and act autonomously & .209 & .273 & -.112 & .281 \\
\hline To have good friends & .212 & .077 & .079 & .185 \\
\hline
\end{tabular}

Method of extraction: Analysis of main components

Method of rotation: Varimax with Kaiser normalization

Rotated matrix of components: The rotation converged after 6 iterations

Table 3: Factor analysis 
Attitude towards PLB was measured using two single-scale items on quality evaluations and worthiness of PLB purchase. They were taken from other studies to this subject (Diallo, Chandon, Cliquet and Philippe, 2013; Boyle and Lathrop, 2013; Seenivasan, Sudhir and Talukdar, 2016). For quality evaluation $(\mathrm{QE})$, the comparative question "How do you evaluate the quality of private label brands compared to national brands?" was used, allowing respondents to select from the three alternatives "superior", "equally" and "inferior" (translated from German). To capture worthiness of PLB purchase (WP), participants had to answer the question "Which statement do you agree the most" using the options "Most of the times, buying national brands is worth the money", "I don't know" and "Most of the times, buying national brands is not worth the money" (translated from German).

\section{Results}

To identify value patterns, data were factor analyzed. Principal component analysis (PCA) with varimax rotation found four stable factors (all item-correlations $>0.5$ ). The factorial structure is shown in table 3. Factors were labeled according to the items included.

Comparing the identified factors with the items on attitude towards PLB reveals that Altruism (factor 1) is positively correlated with perceptions of private labels being superior to that of national brands (QE). The test for factor consistency confirmed the Altruism factor to be sufficiently reliable $($ Cronbach $\alpha=0.723)$.

\begin{tabular}{|c|c|c|c|c|c|}
\hline & & $\begin{array}{l}\text { REGR } \\
\text { factor } \\
\text { score } 1 \text { for } \\
\text { analysis } 1\end{array}$ & $\begin{array}{c}\text { REGR } \\
\text { factor } \\
\text { score } 2 \text { for } \\
\text { analysis } 1 \\
\text { Hedonism }\end{array}$ & $\begin{array}{c}\text { REGR } \\
\text { factor score } \\
3 \text { for } \\
\text { analysis } 1 \\
\text { Performance }\end{array}$ & $\begin{array}{c}\text { REGR } \\
\text { factor score } \\
4 \text { for } \\
\text { analysis } 1 \\
\text { Sense of } \\
\text { family } \\
\end{array}$ \\
\hline $\begin{array}{l}\text { How do you } \\
\text { rate the }\end{array}$ & $\begin{array}{l}\text { Correlation } \\
\text { (Pearson) }\end{array}$ & $.090^{* *}$ & -.009 & .020 & -.027 \\
\hline $\begin{array}{l}\text { quality of } \\
\text { private labels }\end{array}$ & $\begin{array}{l}\text { Significance } \\
(2 \text {-sided) }\end{array}$ & .000 & .631 & .284 & .149 \\
\hline $\begin{array}{l}\text { compared to } \\
\text { national } \\
\text { brands? (QE) }\end{array}$ & $\mathrm{N}$ & 2851 & 2851 & 2851 & 2851 \\
\hline $\begin{array}{l}\text { Most of the } \\
\text { times the }\end{array}$ & $\begin{array}{l}\text { Correlation } \\
\text { (Pearson) }\end{array}$ & -.026 & $.071^{* \star}$ & $.085^{* *}$ & -.020 \\
\hline $\begin{array}{l}\text { buying of } \\
\text { national }\end{array}$ & $\begin{array}{l}\text { Significance } \\
\text { (2-sided) }\end{array}$ & .165 & .000 & .000 & .289 \\
\hline $\begin{array}{l}\text { brands is } \\
\text { worth the } \\
\text { money (WP) }\end{array}$ & $\mathrm{N}$ & 2848 & 2848 & 2848 & 2848 \\
\hline
\end{tabular}

Further, whereas Altruism neither shows a correlation with QE nor with WP, Performance Orientation (factor 2) and Hedonism (factor 3) are positively linked with WP but not with QE. Factor 4 (Sense of Family) is not linked to any of the attitude measures. Table 4 sums up these findings.

\section{Discussion of results and limitations of the study}

A key result is that, for Gen Z, the Altruism factor positively correlates with the belief that PLB have good quality compared to NBs. This is an interesting insight for understanding Gen Z's perception and evaluation of PLB activity in distribution channel management. Essentially, the interaction effect means that either the more altruistic the test persons, the better they evaluate the quality of private labels, or participants who have a positive attitude toward private labels are more altruistic. Interpreting this finding will be a research challenge for the future. One way of reading this effect might be that altruistic people often act in a way that benefits (either directly or indirectly) another third-party individual, without an expectation of reciprocity or compensation. Further, altruism can be a synonym of selflessness 
which is the opposite of selfishness. This includes that the individual itself is less important, and there is no need to make use of impression management techniques like using well known or even luxury brands. Money, success, and status, then, are not important. Manufacturer brands often represent a certain image built by advertising. This image is often hedonistic (the brand is fun like e.g. Coca Cola) or performanceorientated (the brand signifies success, e.g. Hugo Boss). Against this background, Geyskens, Keller, Dekimpe and de Jong (2018) recommend retailers not to use their retailer name for branding PLB if the retailer brand emphasis on status is high. Quite the contrary, private labels often are perceived more "democratic" as they are less associated with manipulation techniques like mass advertising. In their origins, and maybe therefore, these brands were even given brand names like "produits libres" (free products) or "Die Weissen" (the white products - the white labels in a sense of "only the necessary"). Consequently, hedonistic-oriented, or performance-oriented people should prefer NBs which is confirmed by this data set. This seems to hold especially for Gen $Z$ consumers. This is why it might be considered a crucial issue when considering the positioning of future PLB for certain segments on the one hand, and for designing retail channels for Gen $\mathrm{Z}$ target groups on the other. However, the association between familyoriented consumers and the attitude towards PLB remains unclear in this analysis. On the one hand, national brands often adopt happy families as a cue in advertising. In this case, the household responsible may buy national brands to do their family good. On the other hand, families might have to buy private labels because of the household income being rather low. A missing correlation between the sense of family factor and the attitude towards PLB might not be unexpected, therefore. Overall, the findings from this study point towards the following hypotheses: The more Gen $\mathrm{Z}$ consumers advocate altruistic values, the more they believe in the quality of private labels. The more people want to enjoy their lives and the more they perform to be able to buy all they want, the more they believe that having NBs is worth the money. The only value that is relevant for all respondents and correlates with their attitude toward private labels is making new experiences.

Although the data set is based on responses from clients of a particular drugstore company, several results are very similar to more representative studies of young women in Germany. This supports the assumption that the customers in the sample are comparable to the young female population in Germany, and that external validity is sufficient. This might be exemplified with structural criteria like working status or buying motives, for instance. In the study sample used here, $38 \%$ of all participants and $29 \%$ of Gen $\mathrm{Z}$ are working. This is almost congruent with the representative survey by McDonalds and Institut für Demoskopie Allensbach (2017) that found that $25 \%$ of Gen Z are employed (Germany). In another part of the questionnaire, it was asked which criteria were important for product purchase. As a result, the most named criteria are price-performance ratio and quality. This matches findings for young German women from studies reported by Arbeitsgemeinschaft Verbrauchs- und Medienanalyse (VuMA Arbeitsgemeinschaft Verbrauchs- und Medienanalyse, 2018) or Statista and QVC (2017). Thus, there is evidence that external validity is adequate.

A major limitation of the sample, however, is that it is a company survey in a specific sector. Furthermore, it is a female-only sample. A more representative sample, also samples from other countries and industries would be desirable. As the correlations found are quite low, confirmation of the results by further studies is needed. However, the present results are the first indication of a connection between an altruistic attitude and the acceptance of PLB.

\section{Implications for research and management}

This is the first study to examine the link between the values of Gen $\mathrm{Z}$ and their attitude towards PLB using a huge consumer sample of more than 2,500 consumers. Though the study is exploratory and reports only the first symptoms, it offers some interesting implications for retail research and retail channel management.

In terms of marketing and retail research, characteristic values of Gen $\mathrm{Z}$ drugstore customers were factorized, resulting in the four factors Altruism, Performance Orientation, Hedonism, and Sense of Family. This calls for further explorations of these values with other retail branches and also for contrasting the factors to Gen X samples. Moreover, first evidence is provided for how these values relate to the evaluation of PLB. To our knowledge being the first study addressing this relevant relationship, the paper is meant to stimulate further elaboration of this important topic. For that, results from testing with 
other value scales and attitude measures might be compared to the results found here. Doing so, comparing value structures and PLB evaluation of Gen Y to a Gen X sample might offer further insights. This is also true for considering additional moderating or mediating factors to enhance effect sizes. Integrating consumer motives is another relevant aspect future research should consider.

Regarding retail management, this study draws attention to the relevant changes that generational change will mean for PLB strategies. It highlights the underlying value structure which will shape future buying behavior, and especially draws attention to altruistic and performance-related values and motives. Resulting changes in PLB evaluations will have implications for retail assortment in terms of the NB/PLB split, a point that will concern industrial managers as well. Apart from PLB assortment shares, the study also raises questions of how to refine positioning strategies for PLB. For these issues particularly, values related to altruism and performance orientation might be worth being considered for developing new PLB stories or for accessing new target groups. In general, the findings give support to retailers' prominent approaches to invest in PLB, if they focus on altruistic Gen Z consumers in the future. The reason is that, as shown, they are the ones who believe in the quality of PLB products.

In contrast, PLB managers need to be reserved with Gen Z consumers who want to enjoy life, want to perform and want to be able to buy all they want. This group of Gen $Z$ consumers tends to believe that preferring NB to PLB is of higher value. Probably, the core values related to Gen $Z$ might serve as applicable variables for future market segmentation. The insights might have implications for further discussions on what will be a promising positioning strategy for the retailer as a brand, too. All in all, the study reported here reminds retailers and channel managers to acknowledge the relevance of learning more about how Gen Z perceives PLB.

\section{References}

Ailawadi, K. L., Neslin, S. A. and Gedenk, K. (2001). Pursuing the value-conscious consumer: store brands versus national brand promotions, Journal of Marketing, 65(1), pp. 71-89.

Ailawadi, K. L. and Harlam, B. (2004). An empirical analysis of the determinants of retail margins: the role of storebrand share, Journal of Marketing, 68(4), pp. 147-165.

Ailawadi, K. L., Pauwels, K. and Steenkamp, J.-B. E. M. (2008). Private Label Use and Store Loyalty, Journal of Marketing, 72(6), pp. 19-30.

Baltas, G. (1997). Determinants of store brand choice: a behavioral analysis, Journal of Product E Brand Management, 6(5), pp. 315-324.

Baltas, G. and Argouslidis, P. C. (2007). Consumer characteristics and demand for store brands, International Journal of Retail E Distribution Management, 35(5), pp. 328-341.

Batra, R. and Sinha, I. (2000). Consumer-level factors moderating the success of private label brands, Journal of Retailing, 76(2), pp. 175-191.

Beneke, J., Flynn, R., Greig, T. and Mukaiwa, M. (2013). The influence of perceived product quality, relative price and risk on customer value and willingness to buy: a study of private label merchandise, Journal of Product $\mathcal{E}$ Brand Management, 22(3), pp. 218-228.

BMU (2018). Future? Ask youth [Zukunft? Jugend fragen!]. Retrieved from

https://www.bmu.de/publikation/zukunft-jugend-fragen/

Boyle, P. J. and Lathrop, E. S. (2013). The value of private label brands to U.S. consumers: An objective and subjective assessment, Journal of Retailing and Consumer Services, 20(1), pp. 80-86.

Burger, P. C. and Schott, B. (1972). Can private brand buyers be identified? Journal of Marketing Research, 9(2), pp. 219222.

Burt, S. and Davies, K. (2010). From the retail brand to the retailer as a brand: themes and issues in retail branding research, International Journal of Retail E Distribution Management, 38(11/12), pp. 865-878.

Burton, S., Lichtenstein, D. R., Netemeyer, R. G. and Garretson, J. A. (1998). A scale for measuring attitude toward private label products and an examination of its psychological and behavioral correlates, Journal of the Academy of Marketing Science, 26(4), p. 293-306.

Chaney, D., Touzani, M. and Slimane, K. B. (2017). Marketing to the (new) generations: summary and perspectives, Journal of Strategic Marketing, 25(3), pp. 179-189.

Collins-Dodd, C. and Lindley, T. (2003). Store brands and retail differentiation: the influence of store image and store brand attitude on store own brand perceptions, Journal of Retailing and consumer services, 10(6), pp. 345-352.

Corstjens, M. and Lal, R. (2000). Building store loyalty through store brands, Journal of Marketing Research, 37(3), pp. 281-291.

Criteo (2017). Generation Z - The Report [Generation Z - der Report]. Retrieved from 
http://www.criteo.com/de/wp-content/uploads/sites/3/2018/06/GenZ_Report_DE.pdf

Davis, S. (2013). How Target, Walgreens and Home Depot Have Forever Changed the Private Label Game. Retrieved from http://www.forbes.com/sites/scottdavis/2013/05/23/how-target-walgreens-and-home-depot-haveforever-changed-the-private-label-game/

Daymon (2018). Private Brand Intelligence Report 2018. Retrieved from https://www.daymon.com/publications/

Deleersnyder, B., Dekimpe, M., Steenkamp, J. and Leeflang, P. (2009). The Role of National Culture in Advertising's Sensitivity to Business Cycles: An Investigation across Continents, Journal of Marketing Research, 46(5), pp. 623636.

DelVecchio, D. (2001). Consumer perceptions of private label quality: the role of product category characteristics and consumer use of heuristics. Journal of Retailing and Consumer Services, 8(5), pp. 239-249.

Diallo, M.F., Chandon, J.-L., Cliquet, G. and Philippe, J. (2013). Factors influencing consumer behavior towards store brands, International Journal of Retail \& Distribution management, 41(6), pp. p422-441.

Dick, A., Jain, A. and Richardson, P. (1995). Correlates of store brand proneness: Some empirical observations, The Journal of Product and Brand Management, 4(4), pp. 15-22.

Dimock, M. (2019). Defining generations: Where Millennials end and Generation Z begins. Retrieved from http://www.pewresearch.org/fact-tank/2019/01/17/where-millennials-end-and-generation-z-begins /

Erdem, T., Zhao, Y. and Valenzuela, A. (2004). Performance of store brands: A cross-country analysis of consumer store-brand preferences, perceptions, and risk, Journal of Marketing Research, 41(1), pp. 86-100.

Geyskens, I., Keller, K.O., Dekimpe, M.G. and de Jong, K. (2018). How to brand your private labels, Business Horizons, 61(3), pp. 487-496.

Glynn, M. and Chen, S. (2009). Consumer-factors moderating private label brand success: Further empirical results, International Journal of Retail and Distribution Management, 37(11), pp. 896-914.

Gomez-Suárez, M., Quinones, M. and Yagüe, Y. (2017). Private Label Research: A Review of Consumer Purchase Decision Models. In: M. J. Yagüe-Guillén (Eds.), Advances in National Brand and Private Label Marketing (pp. 165172). Wiesbaden: Springer.

Gonzalez-Benito, O. and Martos-Partal, M. (2012). Role of Retailer Positioning and Product Category on the Relationship between Store Brand Consumption and Store Loyalty, Journal of Retailing, 88(2), pp. 236-249.

Herstein, R., Tifferet, S., Abrantes, J. L., Lymperopoulos, C., Albayrak, T. and Caber, M. (2012). The effect of personality traits on private brand consumer tendencies, Cross Cultural Management, 19(2), pp. 196-214.

Hoch, S. J. and Banerji, S. (1993). When do private labels succeed? MIT Sloan Management Review, 34(4), p. 57.

Hsu, H. C. and Lai, C. S. (2008). Examination of factors moderating the success of private label brands: A study of the packaged food market in China, Journal of Food Products Marketing, 14(4), pp. 1-20.

Hyman, M. R., Kopf, D. A. and Lee, D. (2010). Review of literature-Future research suggestions: Private label brands: Benefits, success factors and future research, Journal of Brand Management, 17(5), pp. 368-389.

IPSOS \& Lebensmittelzeitung (2017). Private Labels Study [Handelsmarkenstudie 2017]. Retrieved from https://www.lebensmittelzeitung.net/media/media/13/ Handelsmarkenmonitor-2017-128270.pdf.

Keller, K. (2017). Private Labels: The Brands of the Future. Tilburg: Center for Economic Research.

Kitchen, P. J. and Proctor, T. (2015). Marketing communications in a post-modern world, Journal of Business Strategy, 36(5), pp. 34-42.

Kremer, F. and Viot, C. (2012). How store brands build retailer brand image, International Journal of Retail $\mathcal{E}$ Distribution Management, 40(7), pp. 528-543.

Kumar, N. (2007). Private label strategy: How to meet the store brand challenge. Boston: Harvard Business Review Press.

Labeaga, J. M., Lado, N. and Martos, M. (2007). Behavioural loyalty towards store brands, Journal of Retailing and Consumer Services, 14(5), pp. 347-356.

Lichtenstein, D. R., Ridgway, N. M. and Netemeyer, R. G. (1993). Price perceptions and consumer shopping behavior: a field study, Journal of Marketing Research, 30(2), pp. 234-245.

Lupton, R. A., Rawlinson, D. R. and Braunstein, L. A. (2010). Private label branding in China: What do US and Chinese students think? Journal of Consumer Marketing, 27(2), pp. 104-113.

McDonalds \& Institut für Demoskopie Allensbach (2017). McDonalds qualification study [Die McDonalds Ausbildungsstudie 2017]. Retrieved from https://karriere.mcdonalds.de/docroot/jobboerse-mcd-careerblossom/assets/documents/McD_Ausbildungsstudie_2017.pdf.

Martinez, E. and Montander, T. (2008). Characterisation of Spanish store brand consumers, International Journal of Retail \& Distribution Management, 36(6), pp. 477-493.

Merriman, M. (2015). What if the next big disruptor isn't a what but a who? Gen $\mathrm{Z}$ is connected, informed and ready for business. Retrieved from https://www.ey.com/Publication/vwLUAssets/EY-what-if-the-next-bigdisruptor-isnt-a-what-but-a-who/\$File/EY-what-if-the-next-big-disruptor-isnt-a-what-but-a-who.pdf 
Miquel, M. J., Caplliure, E. M., Pérez, C. and Bigné, E. (2017). Buying private label in durables: Gender and other psychological variables, Journal of Retailing and Consumer Services, 34(Jan), pp. 349-357.

Myers, J. G. (1967). Determinants of private brand attitude, Journal of Marketing Research, 4(1), pp. p73-81.

Nielsen Global Services (2005). The power of private label: a review of growth trends around the world. Retrieved from https://faculty.fuqua.duke.edu/ mela/marketing460/ AtAGlance/ 2005_privatelabel.pdf.

Nielsen US (2018). The Rise and Rise Again of Private Label. Retrieved from https://www.nielsen.com/wpcontent/uploads/sites/3/2019/04/global-private-label-report.pdf

Olbrich, R. and Grewe, G. (2013). Proliferation of private labels in the groceries sector: The impact on category performance. Journal of Retailing and Consumer Services, 20(2), pp. 147-153.

Olbrich, R., Hundt, M. and Jansen, H. C. (2016). Proliferation of private labels in food retailing: a literature overview, International Journal of Marketing Studies, 8(8), pp. 63-76.

Ordun, G. (2015). Millennial (Gen Y) consumer behavior, their shopping preferences and perceptual maps associated with brand loyalty, Canadian Social Science, 11(44), pp. 40-55.

Pauwels, K. and Srinivasan, S. (2004). Who benefits from store brand entry? Marketing Science, 23(3), pp. 364-390.

PLMA (2013). Store Brands Growing Across All Channels. Retrieved from http://plma.com/storeBrands/sbt13.html

PLMA (2019). Store brands surge by $40 \%$ plus in mass retail channel over 5 years, far outpacing national brands. Retrieved from https://www.prnewswire.com/news-releases/store-brands-surge-by-40-plus-in-mass-retailchannel-over-5-years-far-outpacing-national-brands-300835036.html

Richardson, P. S., Jain, A. K. and Dick, A. (1996). Household store brand proneness: a framework, Journal of Retailing, 72(2), pp. 159-185.

Rondan Cataluña, F. J., García, A. N. and Phau, I. (2006). The influence of price and brand loyalty on store brands versus national brands, International Review of Retail, Distribution and Consumer Research, 16(4), pp. 433-452.

Roth, S. and Nazemian, N. (2019). Pragmatically Designing Brand Citizenship Considering Values and Generations [Brand Citizenship wertebasiert, generationsgemäß und pragmatisch aufbauen]. In: F. R. Esch, T. Tomczak, J. Kernstock, T. Langner, \& J. Redler (Eds.), Corporate Brand Management (pp. 357-379). Wiesbaden: Springer.

Rothe, J. T. and Lamont, L. M. (1973). Purchase Behavior and Brand Choice Determinants - National and private brand major appliances, Journal of retailing, 49(3), pp. 19-33.

Rubio, N. and Yagiie, M. J. (2009). The Determinants of Store Brand Market Share: A Temporal and Cross-National Analysis, International Journal of Market Research, 51(5), pp. 501-519.

Schlossberg, M. (2016). Teen Generation Z is being called 'millennials on steroids,' and that could be terrifying for retailers. Retrieved from http://uk.businessinsider.com/millennials-vs-gen-z-2016-2

Sebri, M. and Zaccour, G. (2017). Cross-country differences in private-label success: An exploratory approach, Journal of Business Research, 80(Nov), pp. 116-126.

Seenivasan, S., Sudhir, K. and Talukdar, D. (2016). Do Store Brands Aid Store Loyalty? Management Science, 62(3), pp. 802-816.

Sethuraman, R. and Cole, C. (1997). Why do consumers pay more for national brands than for store brands? Cambridge, MA: Marketing Science Institute.

Shatto, B. and Erwin, K. (2016). Moving on from millennials: Preparing for generation Z, The Journal of Continuing Education in Nursing, 47(6), pp. 253-254.

Sinha, I. and Batra, R. (1999). The effect of consumer price consciousness on private label purchase, International Journal of Research in Marketing, 16(3), pp. 237-251.

Soltan, R. (2004). The Tween Market: Keeping Our Collections Attractive, Practical and Effective. Retrieved from http://www.mlaforum.org/volumeIII/issue1/ Article2Tweens.html

Statista \& QVC (2017). How do you choose cosmetics? (Wonach suchen Sie Gesichtspflege in der Regel aus?). Retrieved from https://de.statista.com/statistik/daten/studie/695168/umfrage/kriterien-beim-kauf-vondekorativer-kosmetik-unter-frauen-in-deutschland/

Steenkamp, J.-B. E.M. an Geyskens, I. (2014). Manufacturer and Retailer Strategies to Impact Store Brand Share: Global Integration, Local Adaption and Worldwide Learning, Marketing Science, 33(1), pp. 6-26.

Ter Braak, A., Geyskens, I. and Dekimpe, M.G. (2014). Taking private labels upmarket: Empirical generalizations on category drivers of premium private label introductions, Journal of Retailing, 90(2), pp. 125-140.

VuMA Arbeitsgemeinschaft Verbrauchs- und Medienanalyse (2018). VuMA Touchpoints 2018. Retrieved from https://www.vuma.de/vuma-praxis/vuma-touchpoints-monitor/

Walsh, G. and Mitchell, V. W. (2010). Consumer's intention to buy private label brands revisited, Journal of General Management, 35(3), pp. 3-24.

Williams, K. C., Page, R. A., Petrosky, A. R. and Hernandez, E. H. (2010). Multi-generational marketing: Descriptions, characteristics, lifestyles, and attitudes, The Journal of Applied Business and Economics, 11(2), pp. 21-36. 